\title{
Chemical Components of Dendrobium polyanthum
}

\author{
Jiang-Miao Hu, You-Xing Zhao, Ze-Hong Miao," and Jun Zhou' \\ State Kev Laboratory of Phytochemistry and Plant Resource in West China, Kumming Instinte of Botan, \\ The Chinese Academy of Science, Kumming 650204, P. R. China. E-mail: jzhouatail kib.ac.cn \\ ${ }^{\dagger}$ Division of Anti-Tumor Pharmacologv. Shanghai Institute of Materia Medica. The Chinese Academy of Sciences. \\ Shanghai 201203, P. R. China \\ Received April 23, 2009. Accepted Alugust 5, 2009
}

\begin{abstract}
A new tetrahydroanthracene, 3,6,9-trihydroxy-3,4-dihydroanthracen-l(2H)-one (1), six phenolics, moscatilin (2), gigantol (3), batatasin (4), moscatin (5), 9,10-dihydromoscatin (6), 10-dilyydrophenanthrene-2,4,7-triol (7), and a sesquiterpenoid, corchoionoside $\mathrm{C}(\mathbf{8})$, together with two sterols $\beta$-sitosterol $(9)$ and dancosterol (10), were isolated from the stems of Dendrobim polyanthm. Compounds $\mathbf{1}$ and $\mathbf{2}$ were assessed for cytotoxic activity against two human tumor cell lines (A549 and HL-60).
\end{abstract}

Key Words: Dendrobium polvanthim, Orchidaceae. Tetrahedroanthracene. Bibenzyl, Phenanthrene

\section{Introduction}

The stems of several Dendrobium species (Orchidaceae) are used as "Shi-Hu" in traditional Chinese medicines to nourish the stomach promote the production of body fluid and reduce fever. ${ }^{1.2}$ Previous studies on chemical constitilents of the genus led to the isolation of a series of diverse compounds, including alkaloids fluorenones. sesquiterpenoids. bibenzyls and phenanthrenes. Some of these compounds were found to possess antitumour activities. ${ }^{3}$ There are about 80 Dendrobium species distributed over China. ${ }^{4}$ A few of them were investigated in this laboratory from 2004 and led to isolation of some new phenolic compounds. ${ }^{56}$ Dentrobitum polyanthum is widely distributed in south-west of China. India. Nepal. Sikkim, Burma. Laos. Vietnam and Thailand ${ }^{4}$ and to the best of our knowledge.

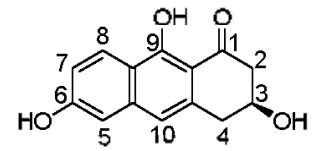

1

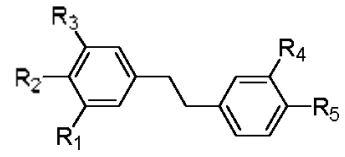

$2 \mathrm{R}_{1}=\mathrm{R}_{3}=\mathrm{R}_{4}=\mathrm{OMe} \mathrm{R}_{2}=\mathrm{R}_{5}=\mathrm{OH}$ $3 \mathrm{R}_{1}=\mathrm{R}_{5}=O \mathrm{OCH}_{3}, \mathrm{R}_{3}=\mathrm{R}_{4}=\mathrm{OH}, \mathrm{R}_{2}=\mathrm{H}$ $4 \mathrm{R}_{1}=\mathrm{R}_{4}=O \mathrm{H}_{1} \mathrm{R}_{3}=\mathrm{OMe}, \mathrm{R}_{2}=\mathrm{R}_{5}=\mathrm{H}$

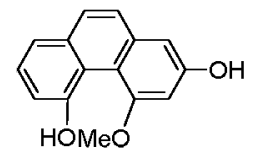

5

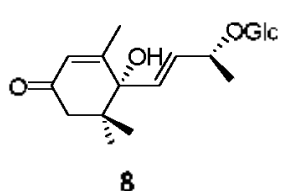

8

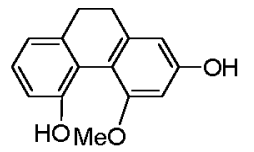

6

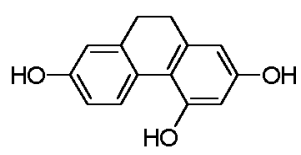

7
Figure 1. Structures of compounds 1-10 from the stems of $D$. primilinum. only two alkaloids, hỵgrine and dendroprimine, have been identified from it by GC-MS method. "In the course of our effort to find biologically active compounds from this species. a new tetrahydroantluracen, (S)-3,6.9-trilyydroxy-3,4-dihydroantluracen-l $(2 H)$-one (1), together with nine known compounds (2-10) were isolated from this plant (Fig. 1). All of these compounds were identified for the first time from $D$. polvanthum in this report. Moreover this is the first time for the isolation of tetrahedroantluracene homologue and corchoionoside C (8) from the genus Dendrobium.

\section{Results and Discussion}

Compound 1 was obtained as a brown anorphous powder, its molecular formula was assigned as $\mathrm{C}_{14} \mathrm{H}_{1} \mathrm{O}_{4}$ from its $\mathrm{HR}$ ESIMS $\left(m / z=267.0639[\mathrm{M}+\mathrm{Na}]^{+}\right)$. indicating 9 degrees of unsaturation. The IR spectrum exhibited lydroxyl group (3394 $\mathrm{cm}^{-1}$. brs: $3296 \mathrm{~cm}^{-1}$, brs). carbonyl bond $\left(1640 \mathrm{~cm}^{-1}\right)$. and aromatic moieties $\left(1592,1534.1484 \mathrm{~cm}^{-1}\right)$. The ${ }^{12} \mathrm{C}$ NMR spectrum of 1 revealed fourteen carbon atoms. including two methylene. five methine. and seven quatemary carbons. Three aromatic atoms at $\delta_{\mathrm{H}}=8.44(\mathrm{lH}, \mathrm{d}, J=2.6 . \mathrm{H}-5) .7 .73(\mathrm{lH}$, dd $J=9.3$. 2.6. H-7) and 10.20 ( 1 H. d. $J=9.3 . \mathrm{H}-8$ ) in the ${ }^{1} \mathrm{H}$ NMR spectrum indicated a 1,2.4-substituted aromatic ring. The signal at $\delta_{\mathrm{H}}=6.99(\mathrm{lH} . \mathrm{s} . \mathrm{H}-\mathrm{l} 0)$ correlated with three carbons at $\delta_{\mathrm{c}}=$ $105.9(\mathrm{C}-5), 128.6$ (C-8a) and 120.4 (C-9a) in the HMBC spectnum (Fig. 2) indicating a naphthalene skeleton. The cross-peaks $[\mathrm{H}-2 / \mathrm{H}-3 . \mathrm{H}-3 / \mathrm{H}-4]$ in the COSY spectrum indicated a partial structure $-\mathrm{CH}_{2} \mathrm{CHOHCH}-$. The partial structure linked with the carbonyl bond $(\mathrm{C}-\mathrm{I})$ and the naphthalene framework ( $\mathrm{C}-9 \mathrm{a}$. $\mathrm{C}-4 \mathrm{a})$ and formed a hexatomic ring by the correlations [H-3]

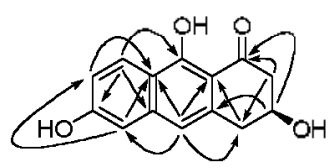

Figure 2. Key HMBC correlations of (S) 3,6,9-trihydroxy-3,4-dihydroanthracen-1 $(2 H)$-one $(1)$. 
C-1. C-4a: H-4 / C-4a, C-9a, C-10] in the HMBC spectrum. Compared the optical rotation $(+21.6)$ of 1 with $(R)$ aloesaponol II $(-43)^{9.16}$ and $(S)$ scytalone $(+32){ }^{11.12}$ it can be established that the compound probably has the $S$ absolute configuration. Thus. compound 1 was identified as (\$) 3.6.9-trihy'droxy-3.4dilydroantluacen-1 $(2 H)$-one.

The nine known compounds were identified on the basis of spectroscopic analy sis and comparing spectra data with literature as moscatilin (2). ${ }^{\top 3}$ gigantol (3). ${ }^{14}$ batatasin (4). ${ }^{15.15}$ moscatin $(5){ }^{18} 9,10$-dihydro-moscatin (6), 10 -dihydrophenanthrene2.4 .7 -triol (7) ${ }^{1 \% 10}$ corchoionoside $C(8)^{-(1.01}$ and by comparing $R_{f}$ values with authentic samples. ${ }^{5,6}$ Some phenolics from Dendrobium species have been reported the antitumor activity ever by some researcher., ${ }^{3,2 . .3}$ thus. compounds $1-2$ were assessed for cytotoxic activity against two human tumor cell lines (A549 and $\mathrm{HL}-60$ ). Compound 2 has a week effect for inhibition ratio of $61.9 \%$ at the concentration up to $10^{-5} \mathrm{~mol} / \mathrm{L}$ and compound 1 has no effect.

\section{Experimental}

General procedures. Melting points were measured on a $\mathrm{XRC}-1$ micro-melting point apparatus (Beijing. China) and were uncorrected. Optical rotations were measured with a Horiba SEAP-300 spectropolarimeter. UV spectra were measured on a Hitachi UV-3210 spectrophotometer (Shanghai. China). IR spectra were measured with a Bio-Rad FTS-135 IR spectrometer (Richmond $\mathrm{CA}$ ) with $\mathrm{KBr}$ pellets. FABMS was obtained on a VG Alto Spec-3000 mass spectrometer (VG. Manchester. England).

Table 1. ${ }^{1} \mathrm{H}$ and ${ }^{1:} \mathrm{C}$ NMR assignments and two-dimensional NMR conelations of 1

\begin{tabular}{|c|c|c|c|}
\hline Position & $\delta_{\mathrm{H}}(\mathrm{mult}, J \mathrm{in} \mathrm{Hz})$ & $\dot{\partial}_{C}($ mult $)$ & $\mathrm{HMBC}(\mathrm{H}-\mathrm{C})$ \\
\hline 1 & & $197.8(\mathrm{~s})$ & \\
\hline $2-\alpha$ & $3.31(1 \mathrm{H}, \mathrm{dd}, J=15.8,3.6)$ & $51.1(t)$ & $1,3,4$ \\
\hline $2-\beta$ & $3.11(1 \mathrm{H}, \mathrm{dd}, J=15.8,9.0)$ & & \\
\hline 3 & $4.62(1 \mathrm{H}, \mathrm{m})$ & $66.4(\mathrm{~d})$ & $1,4 a$ \\
\hline $4-1 x$ & $3.41(1 \mathrm{H}, \mathrm{dd}, J=16.5,3.7)$ & $41.6(t)$ & $2,3,4 \mathrm{a}, 10,9 \mathrm{a}$ \\
\hline $4-\beta$ & $3.27(1 \mathrm{H}, \mathrm{dd}, J=16.5,8.0)$ & & \\
\hline $4 a$ & & $144.5(\mathrm{~s})$ & \\
\hline 5 & $8.44(1 \mathrm{H}, \mathrm{d}, J=2.6)$ & $105.9(\mathrm{~d})$ & $6,7,8 a$ \\
\hline 6 & & $156.4(s)$ & \\
\hline 7 & $7.73(1 \mathrm{H}, \mathrm{dd}, J=9.3,2.6)$ & $121.8(\mathrm{~d})$ & $5,8 \mathrm{a}$ \\
\hline 8 & $10.20(1 \mathrm{H}, \mathrm{d}, J=9.3)$ & $129.4(\mathrm{~d})$ & $10 \mathrm{a}, 6,9$ \\
\hline $8 \mathrm{a}$ & & $128.6(\mathrm{~s})$ & \\
\hline 9 & & $159.3(\mathrm{~s})$ & \\
\hline $9 a$ & & $120.4(s)$ & \\
\hline 10 & $6.99(1 \mathrm{H}, \mathrm{s})$ & $110.1(\mathrm{~d})$ & $4,5,8 \mathrm{a}, 9,9 \mathrm{a}$ \\
\hline $10 \mathrm{a}$ & & $127.7(s)$ & \\
\hline
\end{tabular}

Spectra were recorded in pyridine- $\mathrm{D}_{5 .}$ chemical shifts $(\delta)$ are in ppm. and HR-ESIMS was recorded with an API QSTAR Pulsar 1 spectrometer. ID and 2D NMR spectra were recorded on Buker $\mathrm{AM}-400 \mathrm{MHz}$ and DRX-500 spectrometers (Karlsnihe. Germany), with chemical shifts (ô) in ppm relative to trimethylsilane (TMS) as internal standard and coupling constants in hertz (Hz). Column chromatography was carried out on silica gel (200 300 mesh) and TLC was carried out on plates precoated with silica gel $(10 \sim 40 \mu \mathrm{m}$. Qindao Marine Chenuical Ltd., Qingdao. PRC). Sephadex LH-20 was purchased from Amersham Biosciences.

Plant material. The stems of D. polvanthm were collected in February 2006. from Xishuangbanna. Yunnan Province. China. It was identified by Prof. Yanhui Li (Kunming Institute of Botany). A voucher specimen (No. Zsh-3) was deposited at the state key laboratory of phytochemistry and plant resource in west China of Kumming Institute of Botany. Kumming. China.

Extraction and isolation. The air dried stems of the plant $(3.0 \mathrm{~kg})$ were powdered and extracted with $95 \%$ aqueous $\mathrm{EtOH}$ $(12 \mathrm{~L} \times 3)$ at reflux. The EtOH extract $(36 \mathrm{~L})$ was evaporated under reduced pressure and fractionated successively into EtOAc soluble ( $150 \mathrm{~g}$ ) and $n-\mathrm{BuOH}$ soluble $(80 \mathrm{~g})$ fractions. A portion of EtOAc extract $(1+0 \mathrm{~g})$ was subjected to silica gel columm chromatography (petroleum ether/Me $\mathrm{e}_{2} \mathrm{CO}, 8: 1 \rightarrow 7: 3$ ) to give ten fractions (A-J). Compared $R_{f}$ values by TLC means with authentic sample. compound 9 was identified as the main constituent in the fraction A $(5 \mathrm{~g})$. Fraction $\mathrm{C}(12 \mathrm{~g})$ was applied repeatedly to column chromatography over silica gel (petroleum ether/EtOAc. $8: 1 \rightarrow 7: 3)$ and then Sephadex LH-20 $\left(\mathrm{CHCl}_{3} /\right.$ $\mathrm{CH}_{3} \mathrm{OH} .1: 1$ ) to afford compounds 2 ( $30 \mathrm{mg}$ ). $3(70 \mathrm{mg}), 5(44 \mathrm{mg})$ and 8 (20 $\mathrm{mg})$. By the same methods. compound $4(9 \mathrm{mg})$ was gotton from fraction D $(7 \mathrm{~g})$, compounds $6(7 \mathrm{mg})$ and $7(10 \mathrm{mg})$ were get from fraction $\mathrm{F}(17 \mathrm{~g})$. A portion of $n-\mathrm{BuOH}$ extract (70 g) was subjected to silica gel colunm and eluted with $\mathrm{CHCl}_{3} / \mathrm{CH}_{3} \mathrm{OH}(10: 1 \rightarrow 10: 3)$ to afford six fractions (I-VI). Fraction III (23 g) was applied to column chromatography repeatedly over silica gel $\left(\mathrm{CHCl}_{3} / \mathrm{CH}_{3} \mathrm{OH} .15 ; 1\right)$ and then Sepladex $\mathrm{LH}-20(\mathrm{MeOH})$ to afford compounds $10(50 \mathrm{mg})$ and $1(45 \mathrm{mg})$.

(S) 3,6,9-Trihỵdroxy-3,4-dihydroanthracen-1(2H)-one (1): Brown amorphous powder $\left(\left(\mathrm{CH}_{3}\right)_{2} \mathrm{CO}\right)$. m.p. $242 \sim 244{ }^{\circ} \mathrm{C}$ : $[\alpha]=+21.6(c 0.63, \mathrm{MeOH}): \mathrm{UV} / \mathrm{Vis}(\mathrm{MeOH}) i_{\max }\left(\log \varepsilon_{\max }\right)$ : $357 \mathrm{~nm}$ (3.8). $322 \mathrm{lun}$ (3.9), $255 \mathrm{lun}$ (4.4). $223 \mathrm{~nm}$ (4.4). $201 \mathrm{lum}$ (4.5): $\mathbb{R}(\mathrm{KBr}) v_{\max }: 3394.3362 .2933,1640,1592,1534,1484$. $1401,1314,1268,1233.1146 .1031 .926 .837,657,557 \mathrm{~cm}^{.1}$. ${ }^{1} \mathrm{H}$ NMR (400 MHz pyridine-D5) and ${ }^{13} \mathrm{C}$ NMR (100 MHz. py ridine-D5) data, see Table l: FABMS (positive ion) $m z 245$ (100) $[\mathrm{M}+\mathrm{H}]^{+}$; HR-ESIMS $m z 267.0639[\mathrm{M}+\mathrm{Na}]^{+}$(calcd. 267.0633 for $\mathrm{C}_{1} \mathrm{H}_{1} \mathrm{O}_{4} \mathrm{Na}$ )

Cytotoxic assay. Compound 1 and 2 was tested for its cytotoxic effects against human lung carcinoma A549 and human leukenia $\mathrm{HL}-60$ cell lines using the sulforhodanine $B$ (SRB)

Table 2. The cell growth inhibition rates of compounds 1-2

\begin{tabular}{ccccccccccccc}
\hline cell strain & \multicolumn{1}{c}{ A549 } & \multicolumn{5}{c}{ HL -60} \\
\hline concentration $(\mathrm{mol} / \mathrm{L})$ & $10^{-4}$ & $10^{-5}$ & $10^{-6}$ & $10^{-9}$ & $10^{-8}$ & & $10^{-4}$ & $10^{-5}$ & $10^{-5}$ & $10^{-9}$ & $10^{-8}$ \\
$\mathbf{1}$ & 0 & 0 & 0 & 0 & 0 & & 4.4 & 6.6 & 0 & 0 & 0 & 0 \\
2 & 67.5 & 61.9 & 38.0 & 0 & 0 & 53.0 & 38.2 & 40.2 & 5.4 & 4.7 \\
Etoposide & 88.4 & 60.0 & 27.9 & 11.7 & 7.7 & 89.8 & 91.9 & 91.5 & 82.3 & 66.3 \\
\hline
\end{tabular}


assay and the methyl-thiazol-tetrozolium (MTT) assay, respectively etoposide was used as positive control. The cell growth inhibition rates as shown in Table 2 .

Acknowledgments. This work was financially supported by National Natural and Science Foundations of China (No. 30800090 ) and the Found of State Key Laboratory of Plytochemistry and Plant Resource in West China (P2008-ZZ25). The authors are gratefil to Prof. Hong Yu of Yumnan University for the identification of plant sample and the members of the analytical group of the State Key Laboratory of Phy tochemistry and Plant Resource in West China. Kunming Institite of Botany. for all of the spectral measurements.

\section{Reference}

1. Tiangsu New Medicinal University, Dictionary of Chinese Afediches; Shanghai Scientitic and Technical Publishers: 1986 ; $\mathrm{p} 586$

2. Editing Committee of the Phannacopoeia of China, Phamtcopopia of China, Part I: Chemistry and Industry Press: 2005; p 62

3. Ye, Q. H.:Zhao, W. M: Qin, G. W. In The Progress in Hedicinal Chemistry, Peng, S. X., Ed.; Chemical Industry Press: 2002; vol. 3, p 113.

4. Editing Committee of the Flora of China, Flora of China; Science press: 1999; Vol. 19, p 67.

5. Hu, T. M.; Chen, J. J.; Yu, H.; Zhao, Y. X.; Zhou, J. Jom Jnat of Astan Vatural Products Research 2008, 10,647.
6. Hu, I. M.: Chen, I. T.: Yu, H: Zhao, Y. X.; Zhon, J. Planta Medica $2008,74,535$.

7. Luning, B.; Leander, K. Acta Chemica Scandinavica 1965, 19. 1607.

8. Blomqvist, L.; Leander, K; Luning. B.; Rosenblom, I. Acta Chemica Scandinavica 1972, 26, 3203

9. Yenesew; A.; Ogur, T. A.: Duddeck, H. Phwochemistov 1993, 34 . 1442 .

10. Yagi, A.; Makino, K.; Nishioka, I. Chemical \& Phamacentical Bulletin 1974, 22, 1159 .

11. Bell, A. A.: Stipanovic, R. D.: Puhalla, J. E. Tetrahedron 1976 , 32, 1353.

12. Fabrice, V; Michel, G. Tetrahedron 1990, 16, 2827

13. Majunder, P. L.; Sen, R. C. Plotochemistiv 1987, 26, 2121.

14. Leslie, C.; Jamieson, S. V.J. Chem. Soc., Penkin Trans I 1982, 7, 1467.

15. Majumder, P. L.; Pal, S. Phtochemistry 1993, 32, 1561.

16. Anton, $\mathrm{H}$; Schoenebom, R.; Mues, R. Phtyochemistry 1999, 52. 1639

17. Coxon, D. T.: Ogundana, S. K.: Dennis, C. Phytochemisty 1982. $21,1389$.

18. Honda, C.: Yamaki, M. Plntochemstrv 2000, 53,987.

19. Bhaskar, M. U.: Rao, L. J. M.: Rao, N. S. P.: Rao, P. R. M. J. Nat. Prod. 1991. 5\%. 386.

20. Sawabe, A.; Nesumi, C.; Morita, M.; Matsumoto, S.; Matsubara, $\mathrm{Y}$; Komemushi, S. J. Oleo Science 2005, 5 t, 185.

21. Çalıs, I.; Kuruüzüm-Uz, A.; Lorenzetto, P. A.; Rüedi, P. Plytochemistry 2002, 59,451

22. Lee, Y. H.: Park, T. D.; Baek, N. I.; Kim, S. I.: Ahn, B. Z. Planta Hedica 1995, 61, 178

23. Gong, Y. Q; Fan, Y; Wu, D. Z; Yang, H.; Hu, Z. B.; Wang, Z. T. Enopean Joumal of Cancer 2004, $\$ 0,1554$. 